\title{
A Sociedade Internacional em Francisco Suárez ${ }^{1}$
}

\author{
The International Society in Francisco Suarez
}

\author{
Paulo Emílio Vauthier Borges de Macedo \\ Universidade do Estado do Rio de Janeiro, Rio de Janeiro - RJ, Brasil
}

Resumo: Este texto analisa a noção de sociedade internacional em Francisco Suárez. Porque a vontade constitui elemento essencial do seu conceito de Direito, alguns autores criticaram Suárez por ver nele o precursor do positivismo voluntarista dos teóricos de Direito Internacional do século XIX. Mas isso é um equívoco. A sociedade internacional suareziana é mais do que a mera vontade dos Estados, pois se baseia num conceito bastante transcendente: a Caridade. Assim, neste trabalho, procura-se refutar uma concepção difundida, mas imerecida do teólogo espanhol. O artigo empregou o método de abordagem indutivo e suas fontes primárias foram as obras de Suárez e as secundárias, as dos seus comentaristas.

Palavras-chave: Francisco Suárez. Sociedade Internacional. Voluntarismo.

\begin{abstract}
This text examines the notion of international society in the thought of Francisco Suarez. Since will is an essential element of his concept of Law, some authors have criticized Suarez in regarding him the precursor of the Voluntarist Positivism in International Law theorists of the nineteenth century. However, this is a mistake. Suarezian International society is more than the mere will of the States, because it is based on a concept quite transcendental: Charity. Hence, this work attempts to refute a widely spread yet undeserved misconception of the Hispanic Theologian. This paper has employed the inductive method of approach, and its primary sources were the works of Suarez, and its secondary those of his commentators.
\end{abstract}

Keywords: Francisco Suárez. International Society. Voluntarism.

${ }^{1} \mathrm{O}$ autor agradece o importante apoio e fomento do CNPq.

Recebido em: 15/04/2016

Revisado em: 20/11/2016

Aprovado em: 07/03/2017 


\section{Introdução}

Francisco Suárez, um dos maiores escritores da Escolástica Espanhola, nasceu em Granada, em 5 de janeiro de 1548 e morreu em Lisboa, em 24 de setembro de 1617. Proclamado pela Igreja como Doctor Eximius et Pius, foi um dos fundadores do direito internacional. O internacionalista norte-americano James Brown Scott (1934, p. 183-184), numa feliz analogia, considera Francisco de Vitória o expositor inicial, Francisco Suárez o filósofo, e Hugo Grotius o sistematizador.

Suárez foi um pensador da segunda vaga da Escolástica Espanhola. Os grandes problemas da sua vida, portanto, não são mais aqueles do tempo de Francisco de Vitória: as Grandes Navegações, a descoberta do Novo Mundo e o direito dos índios. Não há dúvidas de que Vitória constitui uma grande referência, e que a colonização e a guerra contra os índios ainda são problemas bastante prementes à época de Suárez. Mas ele teve de lidar com a Reforma, um evento religioso da maior importância para um teólogo católico. E, para aquele que se tornaria um dos primeiros internacionalistas e alguém preocupado em assegurar a universalidade de alguns valores, o fato de a Cristandade não se encontrar mais unida tornaria o gênero humano presa fácil do pensamento cético e relativista em termos morais que se avizinhava com um Charron e um Montaigne.

De fato, foi o teólogo mais importante da Contra Reforma. Quando o rei Jaime I obriga mais um juramento de fidelidade na Inglaterra (o que afastaria o poder do Papa mesmo em questões espirituais) e inicia uma polêmica com o Cardeal Belarmino, Roma recorre ao seu teólogo mais importante da época que eleva a discussão e escreve uma obra científica de mais de oitocentas páginas, a Defensio Fidei Catholicae adversus anglicanae sectae errores. Neste texto, desenvolve concepções bastante modernas, como a origem popular do poder, o contrato social e a ideia de limites ao poder do soberano, muito antes da filosofia britânica.

Suárez desenvolve estes institutos também em razão da sua influência nominalista. No entanto, o que o torna pioneiro na Teoria Política é objeto de críticas bastante severas em Teoria do Direito Internacional. Na primeira metade do século XX, debateu-se, de maneira aguerrida, acer- 
ca da existência de uma verdadeira escola hispânica de Direito Internacional: se entre os escolásticos espanhóis, como, entre outros, o próprio Francisco Suárez, Francisco de Vitória, Domingo de Soto e Luís de Molina, haveria alguma unidade no pensamento jurídico internacional, como existia na Teologia. A tese afirmativa inicia-se com a obra do internacionalista americano J. Brown Scott, hoje já consagrada, El Origen Español del Derecho Internacional Moderno (1928), para quem haveria uma escola espanhola que se inicia com Vitória e termina com um holandês cujo pensamento seria ibérico, Hugo Grotius. Esta posição exerceu um impacto imediato, e essa obra receberia sucessivas reedições.

Todavia, já no ano seguinte, o institucionalista Joseph T. Delos publica o livro La Société Internationale et les Principes de Droit Public (1950, p. 260) no qual defende a tese de que o jus gentium, propugnado por Vitória, e fundado numa ordem axiológica objetiva e institucional, não teria exercido influência imediata nos seus colegas de Salamanca. Ao contrário, Suárez teria corrompido essa ideia ao introduzir elementos voluntaristas e subjetivistas, o que, mais tarde, implicaria uma concepção voluntarista e estatista de direito internacional. Suárez seria, pois, o pioneiro a esposar uma noção própria de internacionalistas como Max Hüber e Dionísio Anzilotti de que o fundamento do Direito Internacional repousaria na vontade dos Estados. Numa versão mais caricata e descrita por Delos, o direito internacional nada mais seria do que um mero disfarce para os interesses egoístas dos Estados.

A concepção desenvolvida neste texto é a de que a hipótese de Delos se apresenta exagerada. Os preceitos de direito das gentes, em Francisco Suárez, não se referem aos Estados - ou, no léxico do autor -, às comunidades perfeitas, de modo isolado, mas ao conjunto delas. Isso faz muita diferença. Da mesma maneira que a autoridade - e o direito nacional, por sua vez - não decorre dos indivíduos, mas da reunião destes em sociedade, o direito das gentes não procede de cada Estado, mas de uma verdadeira sociedade internacional. A reductio ad hitlerum que autores como Delos fizeram constitui nada mais do que um sofisma. 
As referências às obras de Tomás de Aquino e de Francisco Suárez seguem a notação tradicional (sigla, parte ou livro, questão ou capítulo, artigo e as suas divisões internas ou numeração).

\section{Vontade e Intelecto no Conceito de Direito}

Toda a controvérsia sobre a imputação de positivismo em Suárez resume-se ao seu conceito de Direito. Ali é que se pode vislumbrar com clareza a influência nominalista e o consequente "voluntarismo" do autor. Para que se possa compreender o problema, faz-se mister mostrar a tradição tomista na qual o grande teólogo-jurista se inseria.

Em Tomás de Aquino, Direito e Lei, jus e lex, são coisas distintas. O Tratado das Leis deve ser lido em conjunto com o Tratado da Graça, pois tanto as leis como a graça constituem princípios externos ao homem que o movem para a retidão. $\mathrm{O}$ estudo do Direito insere-se no Tratado da Justiça; o objeto de análise da virtude justiça é o direito, o iustum, que corresponde ao dikaion aristotélico. O jus é um ente particular, mas a lex é universal. O jus é res, algo que existe de fato na realidade concreta. A lex é a causa exemplar, o projeto, aquilo para o qual a coisa tende em conformidade com o plano na mente do Criador, mas não a coisa propriamente dita (BASTIT, 1990, p. 163). A confusão entre os dois termos é moderna e possui raízes no ockanismo, mas a distinção é antiga. Os romanos mesmos interpretavam o seu direito como lex, como uma tábua de obrigações (VILLEY, 1990, p. 125). O próprio jus é uma situação, um determinado estado de coisas que se pode considerar justo, mas não algo que pertence ao indivíduo, uma qualidade.

No Aquinate, a lei resume-se, pois, a uma das modalidades ou formas de se realizar a justiça. Mas isso não corresponde a toda a verdade para todos os tipos de lei: somente para a lei humana positiva. As demais cumprem esta e outras finalidades. A lei eterna, por exemplo, consiste no projeto ordenador da razão divina sobre toda a criação: "a lei eterna não é outra coisa senão a razão da divina sabedoria enquanto dirige todos 
os atos e movimentos"2 (ST. 1-2 q. 93 a.1, grifo nosso), mesmo aquelas ações que não partem dos seres humanos. Cabe observar que as demais leis, no Aquinate, não se resumem a uma participação de tipo platônica da ideia sobre o singular concreto; as leis naturais e humanas não constituem um reflexo cada vez mais imperfeito, conforme a distância aumenta, da lei eterna. Expressam, antes, a própria ordem divina em cada nível diferente da realidade.

As leis não devem ser consideradas dentro de uma ordem descendente a partir da lei eterna, mas numa ordem em tensão com a lei de um ser realmente perfeito. [...] Longe de ser um indício de degradação cada vez mais acentuada, a ordem humana torna-se o símbolo dessa tensão fundamental para a perfeição. (BASTIT, 1990, p. 49)3

A justiça e o direito, em Tomás, são singulares concretos que se encontram na ordem humana. É nessa medida que eles se relacionam com a lei. Como o projeto divino se espraia por todos os planos - e a lei eterna passa a realizar-se pela lei natural e, depois, pela lei humana -, o jus, inserto na ordem terrena, termina por se conformar à lex. Em outras palavras, as leis natural e humana constituem a própria lei eterna em planos distintos da realidade. $\mathrm{O}$ direito natural e o direito humano expressam, pois, modalidades concretas de realização da ordenação de Deus.

E por que a lei eterna pode ser considerada "lei", visto que ela se caracteriza por uma relação de causalidade? O que se encontra presente tanto na lei eterna como na lei positiva humana que as caracterizam como singulares da mesma essência de lei? São dois os elementos genéricos o suficiente para reunir num mesmo conceito essas duas formas: razão e exterioridade. No Doutor Angélico, o universal "lei” - emprega-se o termo "universal" para designar a lei em geral, em oposição às diversas espécies de leis: eterna, natural, positiva - corresponde, ao mesmo tempo, a uma

2 "[...] lex aeterna nihil aliud est quam ratio divinae sapientiae, secundum quod est directiva omnium actuum et motionum".

3 "Les lois ne sont plus alors à considérer dans l'ordre descendant à partir de la loi éternelle mais dans une ordre en tension vers la loi d'un être réellement parfait. [...] Loin d'apparaître comme l'indice d'une dégradation de plus en plus accentuée, il devient le signe de cette tension fondamentale vers la perfection." 
razão ordenadora e a um impulso externo ao destinatário da obrigação. Por isso, Tomás de Aquino (ST. 1-2 q. 90 a.1) define a lei como "[...]certa regra e medida dos atos segundo a qual alguém é induzido a agir ou coibido de fazer algo"" E essa indução ou coibição só pode mover os seres racionais para o bem, pois se fundamenta no próprio Deus.

Portanto, a lei, para o Aquinate, consiste num princípio ordenador racional que provém do próprio Deus. Uma vez que se trata de algo que procede de Deus, justifica-se o seu estudo dentro da Teologia. Cabe observar que essa noção de lei difere bastante daquela que os juristas contemporâneos manipulam. Tomás de Aquino a concebe, de fato, como uma ação da substância divina (todas as leis são cossubstanciais a Deus), não como uma norma emanada de uma autoridade que detém o poder político.

Suárez, todavia, tem em mente um objeto muito menos transcendental e mais imanente. Cabe ressaltar que ele reúne, num só tratado, o estudo das leis e do Direito, o que se apresenta bastante revelador: a lei constitui uma das formas de manifestação do Direito (ao lado dos contratos, dos costumes, das sentenças, etc.). Em verdade, o autor considera o conceito tomista muito amplo e genérico. Amplo porque todas as coisas, mesmo as irracionais, possuem uma medida segundo a qual operam. Seres irracionais não são capazes de obediência e, portanto, não podem ser sujeitos de uma lei. Genérico porque a lei deixaria de ser uma propriedade só dos objetos morais ou exclusiva das atividades boas e honestas: objetos artificiais (as técnicas e as artes) e atividades torpes também guiam-se por determinadas regras. Ademais, a definição tomista não basta para diferenciar a força da lei daquela do conselho. Por isso, Suárez afirma que "[...] a lei é um preceito geral, justo e estável, suficientemente promulgado"5 (DL. I, 12, 5). Assim, a vontade do legislador passa a ser essencial para a lei, pois consiste no elemento que a torna obrigatória: a promulgação. A lei, no teólogo granadino, não possui somente uma função indicativa, como a lei tomista, mas também obriga. A lei constitui um preceito racional e um comando expedido por uma vontade eficaz.

\footnotetext{
4 “"...] lex quaedam regula est et mensura actuum, secundum quam inducitur aliquis ad agendum, vel ab agendo retrahitur .[..]".

5 "Lex est commune praeceptum, iustum ac stabile, sufficienter promulgatum".
} 
Aqui, Suárez busca uma via intermediária na famosa controvérsia medieval entre intelectualismo e voluntarismo. Determinada ação constitui pecado, porque Deus proíbe, ou porque Deus proíbe determinada ação, ela constitui pecado? Consoante o voluntarismo, determinado ato é crime, porque Deus ordenou assim. Já segundo a tese intelectualista, não há dúvida de que tudo, mesmo a lei natural, provém de Deus, mas Ele teria criado o cosmo para um propósito bom e nobre, e existem regras que decorrem da natureza e que obrigam as coisas para o seu objetivo final. Este dínamo que move a criação para a sua finalidade é a lei natural (ST. 1-2 q. 90 proemio). Uma vez criadas, tudo aquilo que existe procura atingir a sua própria finalidade, e esse movimento decorre da sua natureza, não da sua criação. Deus pode ser o criador de todas as coisas, mas não é necessariamente o legislador.

Deus teria criado coisas que seriam intrinsecamente boas, e as regras que decorrem da natureza dessas coisas a impelem para o seu bem próprio. O mesmo ocorreria com o homem. Contudo, como este possui livre-arbítrio, ele poderia frustrar os objetivos e, assim, cometer atos que fossem maus em si mesmos: atos que desvirtuam a natureza. O problema que os voluntaristas apontam dessa concepção é que, depois de criado o mundo, a vontade e a autoridade de Deus se tornariam meros acessórios; Ele próprio não poderia mudar a natureza do que criou. Deus não pode fazer com que dois e dois sejam cinco, assim como não pode alterar a essência de um ato bom ou mau. Deus seria subordinado à lei natural, o que representaria um limite ao poder de um Ser onipotente. Porém, para os intelectualistas, Deus é o criador de tudo, mas não necessariamente o legislador: depois da criação, Ele não poderia mudar a ordem, sob pena de emitir dois decretos contraditórios. E não pode haver contradição em alguém perfeito (SCHNEEWIND, 2001, p. 47-51).

O debate entre voluntaristas e intelectualistas influencia sobremaneira Francisco Suárez. Mas não há dúvidas de que a primeira tradição do teólogo espanhol é a tomista; então, primeiro, trata de responder às objeções voluntaristas sobre o problema da limitação do poder de Deus: trata-se de autolimitação. Deus, como ser perfeito, não pode errar, e não pode, portanto, emitir dois decretos contraditórios. Nessa questão, Suárez permanece fiel ao legado intelectualista de Tomás de Aquino e de Fran- 
cisco de Vitória. Para criticar o voluntarismo puro, ele se refere a Gregório de Rimini que apresenta uma variante do que se convencionou chamar de "hipótese impiíssima":

[...] mesmo que Deus não existisse, ou que Ele não fizesse uso da razão, ou ainda que não julgasse as coisas corretamente, ainda assim, se os mesmo ditames da razão justa morassem no interior do homem, constantemente assegurando-lhe, por exemplo, que mentir é ruim, esses ditames ainda assim teriam o mesmo caráter legal que na verdade possuem, porque constituiriam uma lei indicando que o mal existe intrinsecamente no objeto. $(D L . \text { II, } 6,3)^{6}$

Trata-se de uma hipótese que não pode ser aceita: Deus existe e ponto final. Mas pode ser utilizada ad argumentandum. Para Suárez, não há dúvidas de que Deus exista, mas a bondade ou a maldade dos atos não dependem dEle. Uma vez que o bem e o mal existem em si, independente da vontade divina, há, pois, uma moralidade determinada pela natureza. Mesmo que Deus não houvesse prescrito o Decálogo por sua vontade, ainda haveria um pecado que procede da deturpação da essência das coisas, o chamado "pecado filosófico", que atenta somente contra a moral, mas não contra Deus.

Mas Suárez suaviza esse posicionamento e assume uma proposta sincrética. Passa, então, a ponderar os argumentos dos voluntaristas. A primeira condição que se encontra na lei e que a caracteriza como um ato da vontade consiste no fato de que a lei tem por objeto mover e impelir o súdito para a ação ou a omissão, e o princípio que move para a ação é a própria vontade. $\mathrm{O}$ entendimento, no entanto, mais dirige do que move. A segunda característica da lei é ter força para obrigar, e isso reside na vontade, porque o intelecto pode apenas mostrar a necessidade, mas somente a vontade pode impelir em direção a essa necessidade. Ademais, a lei corresponde a um exercício do poder de jurisdição de uma autoridade superior que é, em princípio, uma atividade livre. Por fim, Suárez ( $D L$.

\footnotetext{
6 “[...] licet Deus non esset vel non uteretur ratione vel non recte de rebus iudicaret, si in homine esset idem dictamen rectae rationis dictantis v. g. malum esse mentiri, illud habiturum eandem rationem legis quam nunc habet, quia esset lex ostensiva malitiae, quae in obiecto ab intrinseco existit".
} 
I, 5, 15) aponta que a lei constitui um ato da justiça legal (aristotélica); ainda que a prudência guie a escolha do legislador entre esta ou aquela lei, a fim de realizar o bem comum e conduzir até a justiça distributiva, é a vontade que permite a escolha entre as diferentes opções. Desta feita, a lei possui duas funções: uma diretiva e outra preceptiva; numa orienta, noutra coage.

Mesmo a lei natural compõe-se de intelecto e vontade. O direito natural (o jus natural) consiste numa ordem deontológica de conduta que aflora da natureza humana, mas ele é transformado em formalmente obrigatório pela lei natural. $\mathrm{O}$ bom e o mau são aquelas ações conformes ou não à natureza. Porém, até o momento, a razão apenas indicou, ensinou o que é o bom e o mau. É a lei natural que irá reforçar a obrigatoriedade ao proibir o mau e ordenar o bom. Assim, Deus proíbe o que é mau e prescreve o que é bom, mas as coisas são boas ou más mesmo sem a vontade dEle. E não há qualquer limitação à onipotência divina nessa concepção. Num momento primordial da criação de tudo o que existe, o arbítrio de Deus revela-se ilimitado. Ele pode criar deste ou daquele modo: dois e dois poderiam ser tanto quatro como cinco. Mas, uma vez que já passou o momento da criação, Deus só pode ordenar aquilo que se conforma a ela, sob pena de prescrever dois decretos contraditórios. A contradição num ser perfeito revela-se uma heresia muito mais grave do que uma aparente limitação.

Em Suárez, vontade e intelecto integram a constituição de qualquer lei: eterna, natural e humana. Nas duas primeiras, trata-se da vontade divina, e, na última, a vontade dos homens. No entanto, por causa do primeiro elemento, da razão, Suárez, no que diz respeito às leis civis, não cede à tentação de um voluntarismo à Hobbes. Não basta a lei ser promulgada pela autoridade competente, ela também precisa ser justa. Para Hobbes (2002. p. 112), no estado civil, as leis naturais ainda persistem, mas o soberano torna-se o único que tem a autoridade para interpretá-las. Assim, v.g., o homicídio e o furto ainda constituem violações da lei natural, e as leis civis devem se conformar a essas proibições. Porém, cabe ao soberano, e somente a ele, o direito de determinar que tipo de ação constitui um 
crime. Ele pode, portanto, qualificar de ilícitos atos que, à primeira vista, não pareçam ser e desqualificar outros atos que pareçam ser ${ }^{7}$.

De maneira inegável, essa formulação resulta numa justificação sem freios da soberania estatal; entretanto, ela se encontra em consonância lógica com o pacto de sujeição hobbesiano. O problema é que isso esvazia a lei natural de toda a sua função de modelo, bem como de sua capacidade de contestação da lei positiva. Não há outro critério de justiça das ações do Estado além da vontade do soberano. Não fosse pelo contrato social, Hobbes encontrar-se-ia a um passo de admitir que somente a força produz o Direito.

Em Suárez, a vontade do príncipe não pode ordenar o mal. Somente aquela lei "que é absolutamente medida de retidão e, consequentemente, só aquela que é regra reta e honesta pode chamar-se lei" $(D L . \mathrm{I}, 1,6){ }^{8}$ A força não faz a lei. É claro que o autor sabe que o soberano pode acabar por emitir decretos iníquos que atentem contra a lei natural. Mas ele não aceita que esses decretos possam ser considerados verdadeiras leis. Esse comportamento do soberano poderá ensejar a desobediência civil e, até mesmo, o regicídio, ações que não seriam ilegítimas (ou ilegais) para o autor.

\section{A Caridade como Fonte Material do Direito Internacional}

Como se pode perceber, a vontade, de fato, integra o conceito de Direito suareziano, mas ela é muito sutil e não implica a inversão da frase: "[...] todo o Direito provém da vontade do legislador". Nas relações entre os povos, isso significa que a vontade dos soberanos importa para o direito das gentes, mas este não advém da vontade dos Estados.

Há algo que se encontra além da mera vontade, e, para desvelá-la, faz-se necessário compreender a noção de Estado em Francisco Suárez.

\footnotetext{
7 “O roubo, o assassínio e todas as injúrias são proibidas pela lei de natureza; mas o que há de se chamar roubo, assassínio, adultério ou injúria a um cidadão não se determinará pela lei natural, porém pela civil."

8 “[...] quae est mensura rectitudinis simpliciter et consequenter sola illa, quae est regula recta et honesta, potest lex apellari”.
} 
É claro que não há um conceito de Estado propriamente dito no autor. Isso seria contrafático. Mas o direito das gentes incide nas relações entre povos organizados em comunidades perfeitas. E ele define estas como um agrupamento humano dotado de poder político no qual os homens são capazes de realizar as suas principais necessidades $(D L$. III, 1, 12).

Então, por que Suárez decidiu pensar um jus gentium? Se a comunidade perfeita se define, em oposição à imperfeita (como a família), como aquela em que o homem pode realizar todas as suas necessidades e aspirações, por que cada Estado não se fecha em si mesmo? A teoria política de Suárez parece conduzir à autocracia, o que a tornaria incompatível com a ideia de um direito entre as gentes. Trata-se, contudo, de uma contradição para qualquer jurista ou politólogo, menos para um teólogo. Cabe tecer alguns comentários. Diferentemente do que ocorre com a formação da autoridade no interior de um reino ou de uma república - que, consoante à tradição aristotélica da qual o autor faz parte, se forma pela reunião de famílias, clãs e tribos -, não é a reunião dos mais variados Estados que gera essa sociedade internacional. Em Suárez, esta última possui precedência ontológica: ela já existe e não depende de qualquer associação das diversas comunidades perfeitas. Trata-se da humanidade. Como será visto, o gênero humano preexiste a divisão dos homens nos mais variados povos. Assim, o direito das gentes, segundo o Doutor Exímio e Pio, não é fruto das relações interestatais, não é um direito intercomunidades perfeitas. De fato, ele se insere entre elas (ao menos, o jus propriissime dictum), mas não procede das suas interações. Decorre, em verdade, da dinâmica da vida de uma sociedade jurídica bem mais primitiva e primordial.

A fim de se compreender isso, faz-se necessário retornar à ideia da origem popular da autoridade que o teólogo granadino esposa. Quando Deus criou todas as coisas, pelo mesmo ato, ele repassou o poder a todos os homens, os quais, de imediato, passaram a formar uma espécie de comunidade universal. Porém, isso se apresentava pouco útil e inconveniente para a administração dos recursos e dos bens. Suárez, então, repete um trecho, nas suas adições à teoria do jus gentium, já conhecido do estudo do poder político: 
Por isso, parece-me mais provável que um poder assim para todo o gênero humano não tenha existido, mas, se existiu, foi por brevíssimo tempo. Pouco depois da criação do mundo, começaram os homens a dividir-se em vários Estados, e cada qual com seu poder distinto. (Corpus Hispanorum de Pace, v. XIII, Manuscrito Iure gentium quomodo introducta sint, item 2, 1974, p. 154) ${ }^{9}$

O autor não se preocupa e, até mesmo, nega a existência histórica de um organismo moral de todos os primeiros seres humanos. Mas essa comunidade universal cumpre uma função muito importante como "ideia da razão": uma hipótese meramente intelectual que não precisaria ter existência histórica, mas que os homens precisam agir como se tivesse existido porque serve para justificar um determinado estado de coisas. Foi para esta comunidade universal que Deus conferiu a autoridade inicial sobre toda a Terra.

No corpo principal do De Legibus ac Deo Legislatore mesmo, Suárez revela, com maior eloquência, a noção de que o jus gentium procede da humanidade inteira ( $D L$. II, 19, 9). São apenas dois parágrafos, que ficam a carecer do autor uma explicação, mas vale a pena transcrevê-los na íntegra:

A razão de ser desse direito é que o gênero humano, embora dividido em vários povos e reinos, mantém, em todo o momento, uma certa unidade, não somente a específica [a de pertencermos todos à mesma espécie humana], mas quase política e moral, como indica o preceito natural da caridade e misericórdia [solidariedade] que se estende a todos, inclusive a estrangeiros e a qualquer nação.

Dessa feita, ainda que um Estado, monarquia ou república, seja em si mesmo uma comunidade perfeita e dotada de partes constantes [perenes], sem embargo, cada Estado é também, em relação ao gênero humano, de certo modo um membro dessa comunidade universal. Porque nunca esses Estados, isoladamente considerados, gozam de autonomia tão absoluta que não precisem de alguma ajuda,

\footnotetext{
9 "Unde mihi verisimilius est vel nunquam vel brevissimo tempore fuisse hanc potestatem hoc modo in tota hominum collectione, sed paulo post mundi creationem coepisse homines dividi in varias respublicas est in singulis fuisse hanc potestatem distinctam."
} 
associação ou intercâmbio comum, umas vezes para o seu maior bem-estar, progresso e desenvolvimento, e outras por uma verdadeira necessidade moral e falta de meios, como demonstra a própria experiência ${ }^{10}$.

Nesse texto, encontram-se todos os elementos que fundamentam a concepção suareziana de jus gentium. Luciano Pereña (Corpus Hispanorum de Pace, v. XIII, Estudio preliminar, p. lvii-lx) a decompõe em três ideias principais: a sociabilidade das comunidades perfeitas, a interdependência dos Estados e um conceito relativo de soberania. Uma vez que a humanidade já existia, a sociabilidade dos Estados constitui um postulado natural. Os preceitos de solidariedade e ajuda mútua nada mais expressam do que essa realidade primeira. Além disso, os Estados não podem viver isolados. Necessitam da cooperação para perseguirem seus próprios interesses nacionais. A associação, pois, responde a uma lei progressiva de utilidade comum. Por fim, a sociabilidade e a interdependência terminam por limitar a soberania. Não há comunidade nacional tão perfeita que não possa usufruir do intercâmbio e comércio com outras comunidades.

Os três aspectos brotam do mesmo fundamento. E trata-se de um alicerce extrajurídico. Para perquiri-lo, faz-se mister entender o ponto de partida de Suárez no trecho citado. O autor parte de uma constatação já perceptível em sua época: a humanidade está dividida em diferentes reinos e povos. Isso não representa uma premissa de fé ou uma nostalgia de um período idílico, mas uma afirmação sobre a realidade histórica que Suárez vivia. Essa afirmação assemelha-se bastante com aquela de Maquiavel (1987, p. 7) que abre O Príncipe: “Todos os Estados, todos os do-

\footnotetext{
10 "Ratio autem huius partis et iuris est quia humanum genus, quantumvis in varios populos et regna divisum, semper habet aliquam unitatem, non solum specificam, sed etiam quasi politicam et moralem, quam indicat naturale praeceptum mutui amoris et misericordiae quod ad omnes extenditur, etiam extraneos et cuiuscumque nationis. Quapopter, licet unaquaeque civitas perfecta, respublica aut regnum, sit in se communitas perfecta et suis membris constans, nihilominus quaelibet illarum est etiam membrum aliquo modo huius universi, prout ad genus humanum spectat. Numquam enim illae communitates adeo sunt sibi sufficientes sigillatim, quin indigeant aliquo mutuo iuvamine et societate ac communicatione, interdum ad melius esse maioremque utilitatem, interdum vero etiam ob moralem necessitatem et indigentiam, ut ex ipso constat."
} 
mínios que tem havido e que há sobre os homens foram e são repúblicas ou principados." 11 Ambas constituem constatações de um fato, não um juízo de valor. O jurista conimbricense recorre a um pouco de realismo para soterrar, de vez, o monismo imperial; este, sim, um ideal distante, mas que ainda existia no mundo ibérico na mente de pensadores como o adversário de Bartolomeu de las Casas, Juan Ginés de Sepúlveda, e o grande jurista Ouvidor da Audiência de Lima, Juan de Solórzano Pereira. De fato, o gênero humano encontra-se dividido politicamente.

Suárez concebe, pois, a humanidade como uma árvore que se ramifica em diversos Estados. Ocorre que, entre estes, haveria uma unidade quase política e moral, como uma reminiscência do tronco do qual todos eles constituem ramos. E essa unidade - informa o autor - transcende aquela imposta pela biologia, aquela imposta pelo fato de sermos todos seres humanos. Suárez ilustra essa ligação com o preceito natural do amor e da solidariedade. A ideia racional da comunidade universal primeira subsiste e parece cobrar um retorno a ela própria. Aqui, a concepção definitiva de Suárez acerca do jus gentium ajusta-se de maneira perfeita aos seus primeiros escritos sobre a matéria, quando ele tratou da doutrina da guerra justa. $\mathrm{O}$ fundamento do direito das gentes suareziano reside na maior virtude teologal: a Caridade.

É a Caridade que torna a sociabilidade entre os Estados um dado da natureza; é a Caridade que promove a interdependência de comunidades autocráticas que não necessitam uma das outras; é a Caridade que limita a soberania para além daquilo que foi pactuado. Uma das explicações teológicas mais correntes sobre os motivos que teriam levado um Deus que se basta a si mesmo a criar o mundo é a Caridade. Ele não se sente só e, portanto, não precisa do mundo; entretanto, por amor, quis precisar.

${ }^{11}$ Cumpre salientar que Suárez leu Maquiavel e, como não poderia deixar de fazer, discorda da sua posição, a qual considera "falsa e equivocada". Contudo, o teólogo granadino parece perceber com clareza a distinção - melhor elucidada, séculos depois, pela filosofia alemã - entre um fato e uma norma: “[...] loquor autem de postestate iuris, non facti: nam per erronem saepe Magistratus civilis potest praecipere aliquid iniustum vel illicitum: iure tamen non potest [...] (Refire-se ao poder de direito, não ao fato; porque, por erro, muitas vezes um magistrado civil pode mandar algo injusto ou ilícito, mas em direito não pode fazê-lo)" (DL. III, 12, 4). 
O amor maduro entre um homem e uma mulher não pressupõe nenhuma dependência afetiva ou psicológica de um em relação ao outro. Eles não precisam um do outro para sobreviver. Porém, quiseram precisar. As gentes não dependem uma das outras para satisfazer as suas necessidades, mas quiseram precisar. Não há laço jurídico que obrigue o intercâmbio. Mas a Caridade, como foi visto, extrapola o Direito.

Perceba-se que Suárez escolhe as palavras com muita propriedade. A unidade entre os povos não se revela política, mas "quase". Os preceitos que dela decorrem são de "solidariedade" e "ajuda" - "Caridade" e "misericórdia" no original. Em razão do termo "quase", não se constituiu uma comunidade perfeita de todos os homens, mas há diversos laços que aproximam a humanidade desse tipo de sociedade. E estes elos, "solidariedade" e "ajuda" não possuem essência jurídica. A Caridade não decorre necessariamente da natureza, mas ela se mostra bastante útil para a organização social. Ela pode auxiliar e muito na ordem da sociedade internacional, mas ela pertence a uma esfera superior de realidade. A Caridade representa o motivo pelo qual os preceitos de jus gentium, embora racionais e muito convenientes, não procedem da natureza.

Há certa circularidade no raciocínio, o que deve agradar um teólogo. O fundamento do direito natural, em última análise, é a obediência a Deus. Ele pode ser remetido ao primeiro mandamento de Cristo: amar a Deus sobre todas as coisas. Já o do direito interno se mostra bastante terreno e nada extraordinário: a obediência ao soberano. Se o jus gentium se encontra entre os direitos natural e interno, então o seu fundamento deve também se inserir entre o divino e o terreno. Assim, o fundamento do direito das gentes corresponde ao segundo mandamento de Cristo: o amor ao próximo.

Por isso, apesar de sua vocação universalista, o jus gentium se estende a quase todos os povos. O Direito produz uma obrigação que constrange sempre, mas a Caridade só obriga aqueles povos mais elevados moralmente, como ficou estabelecido pelo mestre Francisco de Vitória (2006, p. 105) no debate sobre a conquista da América: gentes que não oferecem sacrifício humano, nem praticam canibalismo; ou seja, nações que não incorrem em crimes graves contra o segundo mandamento. 
O fato de ser "quase universal" significa que algumas comunidades podem incorrer em erro por algum tempo e, assim, não participar do direito das gentes. Não se deve esquecer, pois, que Suárez é um espanhol que viveu o período da colonização da América.

Afirmar que o fundamento do jus gentium é a Caridade, não o Direito, não o torna "menos jurídico". A fonte formal do direito das gentes são os costumes e os esparsos acordos internacionais que existiam à época do autor, e isso garante a "juridicidade" das normas desse Direito (BORGES DE MACEDO, 2009). A Caridade corresponde à fonte material. A Caridade representa o motivo pelo qual as prescrições de jus gentium obrigam de determinada maneira e não de outra. Em verdade, há um bem comum de toda a humanidade. Mas a virtude que o informa é a Caridade, não a justiça.

Cumpre salientar que nem todos os preceitos da Caridade encontram guarida no direito das gentes. Segundo Suárez, este ramo apresenta poucas normas, as quais visam produzir e conservar apenas uma convivência harmoniosa e pacífica entre as nações. Os tradicionais objetos do jus gentium - o direito da guerra, o direito das embaixadas, o direito de passagem, etc. - remetem-se, de um modo ou de outro, aos princípios da paz e da harmonia entre os povos. $\mathrm{O}$ direito das gentes não se propõe a melhorar o homem espiritualmente, nem a organizar um sistema político. Objetiva, tão somente, manter aberta a comunicação entre os povos para que eles possam, eventualmente, num estágio de maior progresso moral, fomentar a fraternidade e se reconhecer mutuamente como filhos de um mesmo Deus. O jus gentium cria somente as bases, as fundações de um mundo melhor, mas não este mundo melhor. Ele traduz, portanto, um mínimo ético.

$\mathrm{Na}$ sua obra clássica sobre os princípios de direito público, Delos (1950, p. 266) afirma que a visão de Suárez sobre o direito das gentes se enquadra na classificação das concepções subjetivistas. Para o autor, haveria duas posições contrapostas: a de Vitória, orgânica e institucionalista, para quem o Estado consiste num membro de uma sociedade internacional que o preexiste, e a de Suárez, individualista e voluntarista, para quem o Estado precederia a sociedade internacional, e esta seria formada 
pela interação dos diversos países. O direito das gentes, por conseguinte, dependeria da vontade dos povos e não possuiria uma existência objetiva. Delos reconhece que a sua hipótese não se coaduna com a de Heinrich Rommen (1951, p. 474), um dos maiores intérpretes de Suárez, mas, na história do direito público, os publicistas só poderiam filiar-se a uma dessas duas correntes.

No entanto, se há algum voluntarismo em Suárez, mesmo assim isso não retira a "objetividade" do jus gentium. Delos equivoca-se em não estabelecer nuanças entre as duas opções. Perceber que a abordagem de Suárez é a de um teólogo, não a de um jurista, ajuda a compreender a sua posição matizada. A humanidade - que está ligada por laços de Caridade - tem precedência ontológica em relação aos Estados, os quais constituem apenas a sua manifestação histórica. Ao conceber a humanidade como um universo que se divide em Estados, e o jus gentium o direito não das relações entre os povos, mas dessa humanidade, Suárez possibilita uma ordem jurídica objetiva, sem necessitar recorrer à figura de uma federação mundial, como nos projetos de paz perpétua, tipicamente modernos. Na concepção suareziana, há valores que não dependem dos Estados para serem válidos. O direito das gentes não requer a vontade dos Estados para existir. Ele existe antes do aval destes.

\section{Conclusão}

A doutrina da sociedade internacional de Francisco Suárez corresponde a uma formulação típica de um teólogo da escolástica espanhola tardia. Diferentemente do que ocorre com o Deus protestante, entre o Deus católico e os seres humanos, não existe um hiato tão grande que só se possa transpor pela fé. O Deus de Suárez não abandonou os homens à sua própria sorte e criou uma série de instituições, como as leis e a graça, que servem para admoestá-los e corrigi-los. Os direitos natural, civil e das gentes, cada qual em seu âmbito de aplicação e validade, constituem instrumentos da ação divina. Toda a filosofia jurídica do autor representa formas de exercício da providência divina. 
Suárez inova em relação ao tomismo tradicional pelo fato de haver descoberto, em sua Teologia, um espaço eminentemente humano. Trata-se de um domínio com dignidade própria e autônomo. Desta feita, embora o propósito da lei natural, cujo legislador é Deus, seja tornar o homem bom, e, possua, portanto, uma natureza transcendental; o da lei civil, promulgada por homens, é o bem comum, e, assim, encontra-se bastante inserido na imanência. Resta, ainda, uma transição entre o divino e o humano que precisa efetuar-se. Essa missão cabe ao jus gentium. Ele visa estabelecer um mínimo de civilidade entre os povos e organizar uma coexistência pacífica e harmoniosa.

O autor concebe a humanidade como uma árvore que se divide em diversos Estados. Ele afirma isso de maneira contundente. Mas sutil revela-se a percepção de que o direito das gentes não decorre das relações entre os Estados, da interação entre os ramos. Trata-se de um fruto do próprio tronco, da humanidade. Embora esta não forme uma comunidade perfeita, o teólogo granadino afirma que há laços de caridade que unem os diversos povos. O jus gentium representa um mínimo ético entre povos civilizados.

A classificação que Delos procura impingir a Suárez não pode ser aceita; a doutrina do Doutor Exímio contrapõe-se, de fato, às teorias subjetivistas. Em razão do direito das gentes proceder da humanidade, não da vontade dos Estados, este ramo expressa uma ordem jurídica de valores objetivos.

\section{Referências}

AQUINO, Tomás de. Suma Teologica. Texto latino de la edición crítica Leonina. Trad. Francisco Barbado Viejo, O. P. 2. ed. Madrid: Biblioteca de Autores Cristianos, 1947.

BASTIT, Michel. Naissance de la loi moderne: la pensée de la loi de saint Thomas à Suarez. Paris: Presses Universitaires de France, 1990.

BORGES DE MACEDO, Paulo Emílio. O nascimento do direito internacional. São Leopoldo: EdUNISINOS, 2009. 
DELOS, J. T. La Société Internationale et les Principes de Droit Public. 2. ed. Paris: Pédone, 1950.

HOBBES, Thomas. Do Cidadão. Trad. Renato Janine Ribeiro. São Paulo: Martins Fontes, 2002.

MAQUIAVEL, Nicolau. O Príncipe. Trad. Lívio Xavier. São Paulo: Abril Cultural, 1987.

ROMMEN, Heinrich. La Teoria del Estado y de la Comunidad Internacional en Francisco Suárez. Tradução para o espanhol de Valentin Garcia Yebra. Buenos Aires; Madrid: Facultad de Derecho y Ciencias Sociales y Instituto de Derecho Internacional; Instituto Francisco de Vitória y Consejo Superior de Investigaciones Cientificas, 1951.

SCHNEEWIND, J. B. A invenção da autonomia: uma história da filosofia moral moderna. Trad. Magda França Lopes. São Leopoldo: UNISINOS, 2001.

SCOTT, J. B. El Origen Español del Derecho Internacional

Moderno. Valladolid: Universidad de Valladolid, Sección de Estudios Americanistas, 1928.

. The Catholic Conception of International Law. Washington D.C.: Georgetown University Press, 1934.

SUÁREZ, Francisco. De Legibus. ed. crítica e bilíngüe por Luciano Pereña. Madrid: Consejo Superior de Investigaciones Cientificas, 1974. (Corpus Hispanorum de Pace, v. XIII).

. Tratactus de legibus, ac Deo Legislatore in decem Librus distributus. Venetiis: Sebastianum Coleti, 1740.

VILLEY, Michel. Le Droit et le droit de l'Homme. 2. ed. Paris: Presses Universitaires de France, 1990.

VITÓRIA, Francisco de. Os índios e o direito da guerra. Trad. Ciro Mioranza. Ijuí: Unijuí, 2006. 
Paulo Emílio Vauthier Borges de Macedo é professor de Direito Internacional Público na Universidade do Estado do Rio de Janeiro (UERJ), doutor em Direito pela mesma instituição e pós-doutor pelo Instituto Histórico e Geográfico Brasileiro (IHGB).

E-mail: vauthierborges@yahoo.com.br.

Endereço profissional: Universidade Estadual do Rio de Janeiro, Faculdade de Direito, Pavilhão Reitor João Lyra Filho, Rua São Francisco Xavier n. 524, Maracanã, Rio de Janeiro, RJ - 20550-900. 